\title{
An Empirical Analysis of the Impact of Government Spending on Agriculture in Nigeria
}

\author{
Abubakar Sadiq Iliyasu ${ }^{1,2^{*}}$ \\ 1.University of Greenwich, Old Royal Navy College, Park Row, London SE10 9LS, UK \\ 2.SEGi College, USJ 1, 47600 Subang Jaya, Selangor, Malaysia
}

\begin{abstract}
This study examined the relationship between government spending and real and nominal agricultural sector activity in Nigeria between 1999 and 2016 using linear regression analysis and found that though government spending on agriculture had a positive relationship with the sector and its subsectors, this relationship was insignificant and recommended that government spending should be more accountable and should also not be seen as the sole option towards reviving this sector as other measures can be used in sync for optimal results.

Keywords: Government Spending, Agriculture, Crops, Livestock, Forestry, Fishing, Fiscal Policy, Nigeria, Africa. DOI: $10.7176 / \mathrm{JESD} / 10-24-02$

Publication date: December $31^{\text {st }} 2019$

\section{Acknowledgement}

Special thanks to my lecturers, Mr. Nizar Ali Khan and Mr. Cai Yunchao for their counsel and assistance with this study. I would also like to thank the University of Greenwich and SEGi College for providing the opportunity and means to conduct this study.
\end{abstract}

\section{Introduction}

For Nigeria's agricultural sector has been in inertia for a few decades after showing much promise in the period shortly after its independence. This decline was brought about by the discovery of fossil oil which led to the abandonment of this sector for the more lucrative oil sector. Though most governments afterwards have emphasized their commitment to reviving this sector most of their efforts have proven futile and agriculture still very much remains an underdeveloped sector with the country importing most of its food. Now more than ever it is important to understand how effective government policies are on this sector in order to improve decisions in the future.

Today, governments use taxation and spending impact to an economy, this is known as fiscal policy. This may come in the form of expansionary fiscal policy where the government tries to advocate economic growth by cutting taxes and increasing spending, or contractionary fiscal policy where it tries to curb economic growth by increasing taxes and spending less. Economic growth is the rise in a country's Gross Domestic Product. The more a government spends the larger effect it will have on GDP. Most economists recommend large spending for developing countries like Nigeria to create investment, increase the circulation of money and create unemployment opportunities. The more it spends on an industry the more this industry grows and the more it contributes to its economy.

This research will be focused on government spending directed towards Nigeria's agricultural sector.

The Nigerian government annually sets apart a chunk of its annual budget to be directed at the agricultural sector for capital and recurrent expenditure. Capital expenditure is aimed towards purchase of assets considered as fixed asset such as lands and impedimenta and for projects while recurrent expenditure includes operational costs. However, many have pointed out flaws in the states spending. When comparing Nigeria's expenditure on agriculture to that of most countries even when considering to national income percentage, it lags behind most countries. In 2008, a study by the International Food Policy Research Institute examined government expenditure on agriculture in Nigeria between 2001 and 2005 and found it to be exceptionally low at two percent especially when comparing it to other important sectors like health and education (Dillon 2008). This also percentage is significantly less than 10 percent objective agreed to by African states under the Maputo agreement in 2003, raising questions the Government's commitment to diversification. The 2007 World Bank Development report also noted that investment in Nigeria's agricultural sector has been minimal.

Research Objectives

- To determine the nature of the relationship between government spending whether positive or negative

- To determine whether this relationship is significant.

\section{Theoretical Framework}

Keynes general theory emphasized the need for demand in an economy. He outlined the need for governments to spend to encourage economic growth by creating demand because he saw government spending as a component of GDP. He also stated that taxation had an impact and consumption and real sector spending so when taxes are 
higher investment and is lower and when taxes are lower investment and spending is higher because both consumers and investors stand to gain more. This will in turn spur economic growth. This need for fiscal policy is heightened especially during periods of low productivity or economic difficulties like what Nigeria is going through. (Keynes, 1936)

Most countries today use a mixed economy and subscribe to the fundamentals of Keynes assumptions and so act in accordance with it, taking his recommended steps for growth and contraction when necessary.

Using this framework, it is only logical to assume that the sectors where fiscal policies are centered should excel in a country and as such taxation and spending should have an effect such that higher spending should result in growth of the agricultural sector and lower taxes should increase investment and consumption in this sector, encouraging its growth.

\section{Literature Review}

\subsection{Nigeria}

Multiple studies have targeted the effect of fiscal policy on agriculture. Perusing data from Nigeria's agricultural sector spending from 1979-2007, Lawal (2011) set out to confirm figures of agricultural spending. He found that although there is no standard pattern for Nigeria's agricultural spending, government spending directly correlated with the sectors contribution to GDP.

Similarly, Adofu et al (2012) tried to examine how government expenditure impacted the agricultural sector in Nigeria between 2005 and 2009. They found that the amount or percentage of Nigerias budget allocation to the agricultural sector had a direct relationship with its output.

Shuaib et al (2015) examined the impact of government agricultural expenditure on the growth of the Nigerian economy between 1960 and 2012. Using co-integration and pairwise granger causality tests, they found a direct relationship between economic growth and government agricultural expenditure. Based on this result they emphasized on the need for the Nigerian government to increase spending through handing out and ensuring financial institutions allocate low interest loans to small farmers in order to curb hunger and adequately diversify the country's economy.

Ademola et al (2013) studied the impact of federal expenditure on the agricultural sector and economic growth between 1981 and 2010. Complimenting ordinary least squared using co integration and unit root for appraisal of non-significance or significance of the manufacturing sector to Nigerian economic growth. They found a significant relationship between independent and dependent variables and detected a positive relationship between federal expenditure and the growth of the agricultural sector. They noted the role of agriculture on economic growth and stressed the need for the state to encourage activities in this sector.

Ebere \& Osudina (2012) similarly examined the impact of the state's agricultural expenditure using and ordinary least square and multiple linear regression. They found a direct positive relationship between government spending and the output of the agricultural sector and also found a significant positive effect of agricultural output and economic growth in the country in line with studies by Bhatia (2009) and other preliminary studies. Statistically, they found that a $1 \%$ increase in federal spending resulted in a $1.63 \%$ increase in GDP expansion. Their recommendations also focused on prioritizing the agricultural sector and diversification like previous studies.

A more comprehensive study was carried out by Olomola et al (2014) which examined public agriculture spending on local, state and federal government levels based on level and composition. Although on a positive note commended this sectors growth in recent times, they stipulated that this sector was extremely underfunded. They also dreaded the efficiency of implementing and allocating federal spending and since state spending relies on federal allocations, delay in transfers, oil price fluctuations and other factors cause inefficiency and inconsistency in state spending as well. They highlighted the need to improve allocation and improvement efficiency, increase spending, improve federal budget process and revamp agricultural public spending information management in order to maximize gains from federal spending on the agricultural sector.

Apata et al (2016) compared public agricultural spending and agricultural growth between Nigeria and Malaysia. They found a relationship between government spending and agricultural growth in these two countries with Malaysia reaping positive benefits of this relationship and Nigeria reaping the opposite due to low funding. They recommended that the Nigerian policy makers curb spending on unproductive sectors and focus on this sector, especially towards activities that galvanize more growth including foreign transactions; for instance, import of capital goods and spending on the private domestic sector.

Another study on Nigeria carried out by Iganiga \& Unemhilin (2011) examined how the policy focus on agricultural spending impacts the agricultural sector. They detected policy flaws as expenditure was not adequately allocated to activities like irrigation, construction of credit facilities and importation of advanced farming implements and techniques which they felt could compliment other efforts and boost productivity in the sector. They also encouraged a food importation ban to encourage local production.

It can be seen that most research affirms a direct relationship between government spending and agricultural expenditure in Nigeria such that more spending leads to more productivity and output. 


\subsection{India}

A comprehensive study on the footprint and pattern of state spending on agriculture in India for a 39 year period from 1951 to 1989 was carried out by Selvaraj (1993). He found that a 10\% increase in spending causes a 7\% increase in agricultural output and that because of this significant relationship, this sector was underachieving due to India's falling federal agricultural expenditure. He suggested that rather than cut spending haphazardly, they should focus spending on providing amenities for agriculture like irrigation, research and infrastructure to stimulate growth of the economy and tackle hunger poverty and various other issue. He however noted that higher spending resulted in higher instability in the sector.

\subsection{Malawi, South Africa, Tanzania, Zambia}

Jambo (2017) studied the trend and impact of fiscal policy on these four African countries. Using data between 2000 and 2014. Though noting a mismatch between allocated budget and actual spending due to unrealistic budgets and budget deviations, they found varying effects for agricultural spending in these countries. In South Africa, they found that a $1 \%$ rise in federal spending on agriculture led to $1.03 \%$ surge in agriculture growth and while spending in agricultural growth in South Africa was in line with government spending this was not the case for Zambia and Malawi. In Zambia, spending on agricultural research had a negative effect on agricultural growth while it had a positive effect in Tanzania and Malawi (13\% growth for every $1 \%$ increase in spending). These deviations which they attribute to unreliable data made it objectionable to find a suitable universal recommendation for all countries. While Malawi and South Africa should continue their spending trend, In Zambia, they recommended that instead of increasing agricultural spending on research, it is more effective to spend on infrastructural development which they found had a better correlation with their agricultural growth. They further recommended the removal of export bans on some agricultural produce in Tanzania in order to achieve greater growth and improve trade balance.

\subsection{Nepal}

Wagle (2016) investigated the nexus between government spending and agriculture in Nepal for data collected between 1983 and 2014. Though finding a significant positive impact on agriculture due to spending, they noticed that it was too insignificant to have any major effect on Nepal's economy and even more so now that the country is becoming less dependent on its agricultural sector and their unskilled labor force is experiencing a diminishing return to scale.

\subsection{Pakistan}

Chandio et al (2016) probed how overall economic growth was influenced by public spending on agriculture between 1983 and 2011 using ADF OLS and Johansen co integration to analyze data. They found a long run correlation between these variables and that public spending does stimulate agricultural and general economic growth in Pakistan. The relationship is such that a $1 \%$ increase in government spending on agriculture will boost the economy by $0.09 \%$ and a $0.57 \%$ increase in economic growth results from $1 \%$ increase in agricultural output. He subsequently endorsed increased funding for the agricultural sector for economic growth.

\subsection{Thailand}

Jaroensathapornkul \& Tongpan (2007) scrutinized how government spending fueled increased in consumption in Thailand has impacted its agricultural sector. They found that government sector increased the consumption, import and export of agricultural products. However, the country experienced extended shocks on employment and capital sector and the deficit balance of the current account increased. They advocated for a more intensive and advanced approach to studying this topic while also bemoaning inability to segregate date from the agricultural sector.

\subsection{Ukraine}

Shevchuk \& Kopych (2017) inspected fiscal policy effects on agriculture and industry in Ukraine between 2001 and 2016 using quarterly data. They concluded that federal spending had positive effect on both dependent variables, advising against removal of state fiscal support for industry and agriculture. They however pled for caution when spending as it causes nominal exchange rate depreciation and may suppress this industry due to this.

\section{Research Hypothesis}

Hypothesis 1

$\mathrm{H}_{0}$ There is no significant relationship between federal capital expenditure and crop production.

$\mathrm{H}_{1}$ There is a significant relationship between federal capital expenditure and crop production

Hypothesis 2

$\mathrm{H}_{0}$ There is no significant relationship between federal capital expenditure and Livestock farming. 
$\mathrm{H}_{1}$ There is a significant relationship between federal capital expenditure and livestock farming.

Hypothesis 3

$\mathrm{H}_{0}$ There is no significant relationship between federal capital expenditure and forestry.

$\mathrm{H}_{1}$ There is a significant relationship between federal capital expenditure and forestry.

Hypothesis 4

$\mathrm{H}_{0}$ There is no significant relationship between federal capital expenditure and fishing.

$\mathrm{H}_{1}$ There is a significant relationship between federal capital expenditure and fishing.

Hypothesis 5

$\mathrm{H}_{0}$ There is no significant relationship between federal capital expenditure and agriculture.

$\mathrm{H}_{1}$ There is a significant relationship between federal capital expenditure and agriculture.

\section{Data Collection}

For this research, data was from the Central Bank of Nigeria on agricultural activity which was further divided into its four main sectors, crops, livestock, forestry and fishing in other to get more comprehensive results. Figures on capital expenditure were collected from the budget office of the federation.

5.1 Variables and Data Source

\begin{tabular}{|l|l|}
\hline Variable & Source \\
\hline Crops (Real, Nominal) & Central Bank of Nigeria (CBN) \\
\hline Livestock (Real, Nominal) & Central Bank of Nigeria (CBN) \\
\hline Forestry (Real, Nominal) & Central Bank of Nigeria (CBN) \\
\hline Fishing (Real, Nominal) & Central Bank of Nigeria (CBN) \\
\hline Agriculture (Real, Nominal) & Central Bank of Nigeria (CBN) \\
\hline Federal Capital Expenditure (Agricultural Sector) & Budget Office of the Federation (BOF) \\
\hline
\end{tabular}

Table 1: Data Sources

\subsection{Tests}

Correlation tests were carried out using the IBM SPSS correlation analysis and regression analysis. Result tables used can be found in the appendix. Hypothesis was tested for nominal and real values for the dependent variables.

\begin{tabular}{|c|l|}
\hline Test & Purpose \\
\hline Pearson & To determine if a statistical relationship exists between our variables. In this case federal \\
Correlation & capital expenditure is the independent variable while agricultural and its subsectors is the \\
Analysis & independent variable. \\
\hline
\end{tabular}

Table 2: Tests

Testing Hypothesis 1

$\mathrm{H}_{0}$ There is no significant relationship between federal capital expenditure and crop production.

$\mathrm{H}_{1}$ There is a significant relationship between federal capital expenditure and crop production.

Correlations

\begin{tabular}{|ll|l|l|}
\hline & & Federal Capital Expenditure & Crops \\
\hline Federal Capital Expenditure & Pearson Correlation & 1 & .412 \\
& Sig. (2-tailed) & & .089 \\
& $\mathrm{~N}$ & 18 & 18 \\
\hline Crops & Pearson Correlation & .412 & 1 \\
& Sig. (2-tailed) & .089 & 18 \\
\hline
\end{tabular}

Table 3: Correlation 1.1 
A Pearson correlation test showed a moderate positive correlation between federal capital expenditure and nominal crop production $(\mathrm{r}=.412)$. However, this relationship is insignificant $(\mathrm{p}=.089)$ using a 0.05 level of significance.

Correlations

\begin{tabular}{|ll|l|l|}
\hline & & Federal Capital Expenditure & Real Crops \\
\hline Federal Capital Expenditure & Pearson Correlation & 1 & .441 \\
& Sig. (2-tailed) & & .067 \\
& $\mathrm{~N}$ & 18 & 18 \\
\hline Real Crops & Pearson Correlation & .441 & 1 \\
& Sig. (2-tailed) & .067 & 18 \\
& $\mathrm{~N}$ & 18 & 18 \\
\hline
\end{tabular}

Table 4: Correlation 1.2

Similarly, the correlation test found an insignificant positive relationship between federal capital expenditure and real crop production $(\mathrm{p}=.441, \mathrm{r}=.067)$.

Based on this, there is no sufficient evidence to reject $\mathrm{H}_{0}$.

Testing Hypothesis 2

$\mathrm{H}_{0}$ There is no significant relationship between federal capital expenditure and Livestock.

$\mathrm{H}_{1}$ There is a significant relationship between federal capital expenditure and Livestock.

\begin{tabular}{|c|c|c|c|}
\hline & & Federal Capital Expenditure & Livestock \\
\hline Federal Capital Expenditure & $\begin{array}{l}\text { Pearson Correlation } \\
\text { Sig. (2-tailed) } \\
\mathrm{N}\end{array}$ & $\begin{array}{l}1 \\
18 \\
18\end{array}$ & $\begin{array}{l}339 \\
169 \\
18\end{array}$ \\
\hline Livestock & $\begin{array}{l}\text { Pearson Correlation } \\
\text { Sig. (2-tailed) } \\
\mathrm{N}\end{array}$ & $\begin{array}{l}.339 \\
169 \\
18 \\
\end{array}$ & $\begin{array}{l}1 \\
18\end{array}$ \\
\hline
\end{tabular}

Table 5: Correlation 2.1

Correlations

\begin{tabular}{|ll|l|l|}
\hline & & Federal Capital Expenditure & Real Livestock \\
\hline Federal Capital Expenditure & Pearson Correlation & 1 & .449 \\
& Sig. (2-tailed) & & .061 \\
& $\mathrm{~N}$ & 18 & 18 \\
\hline Real Livestock & Pearson Correlation & .449 & 1 \\
& Sig. (2-tailed) & .061 & \\
$\mathrm{~N}$ & 18 & 18 \\
\hline
\end{tabular}

Table 6: Correlation 2.2

A weak insignificant positive relationship is found between federal capital expenditure and livestock $(\mathrm{p}=.339, \mathrm{r}$ $=.169$ ). When testing correlation between federal capital expenditure and real livestock, a moderate but insignificant correlation was found $(\mathrm{p}=.449, \mathrm{r}=.061)$.

Based on this there is no sufficient evidence to reject $\mathrm{H}_{0}$.

Testing Hypothesis 3

$\mathrm{H}_{0}$ There is no significant relationship between federal capital expenditure and Forestry.

$\mathrm{H}_{1}$ There is a significant relationship between federal capital expenditure and Forestry.

\section{Correlations}

\begin{tabular}{|ll|l|l|}
\hline & & Federal Capital Expenditure & Forestry \\
\hline Federal Capital Expenditure & Pearson Correlation & 1 & .368 \\
& Sig. (2-tailed) & & .133 \\
& $\mathrm{~N}$ & 18 & 18 \\
\hline Forestry & Pearson Correlation & .368 & 1 \\
& Sig. (2-tailed) & .133 & 18 \\
& $\mathrm{~N}$ & 18 & 18 \\
\hline
\end{tabular}

Table 7: Correlation 3.1 


\section{Correlations}

\begin{tabular}{|ll|l|l|}
\hline & & Federal Capital Expenditure & Real Forestry \\
\hline Federal Capital Expenditure & Pearson Correlation & 1 & .396 \\
& Sig. (2-tailed) & & .104 \\
& N & 18 & 18 \\
\hline Real Forestry & Pearson Correlation & .396 & 1 \\
& Sig. (2-tailed) & 104 & \\
N & 18 & 18 \\
\hline
\end{tabular}

Table 8: Correlation 3.2

Tests showed a weak insignificant positive relationship between federal capital expenditure and forestry $(p=.368$, $\mathrm{r}=.133)$ and likewise a weak insignificant positive relationship between capital expenditure and Real Forestry ( $\mathrm{p}$ $=.396, \mathrm{r}=.104)$.

Based on this, there is insufficient evidence to reject $\mathrm{H}_{0}$.

Testing Hypothesis 4

$\mathrm{H}_{0}$ There is no significant relationship between federal capital expenditure and Fishing.

$\mathrm{H}_{1}$ There is a significant relationship between federal capital expenditure and Fishing.

\section{Correlations}

\begin{tabular}{|ll|l|l|}
\hline \multicolumn{1}{|c|}{} & Federal Capital Expenditure & Fishing \\
\hline Federal Capital Expenditure & Pearson Correlation & 1 & .314 \\
& Sig. (2-tailed) & 18 & .204 \\
& $\mathrm{~N}$ & .314 & 18 \\
\hline Fishing & Pearson Correlation & .204 & 1 \\
& Sig. (2-tailed) & 18 & 18 \\
\hline
\end{tabular}

Table 9: Correlation 4.1

\section{Correlations}

\begin{tabular}{|ll|l|l|}
\hline & & Federal Capital Expenditure & Real Fishing \\
\hline Federal Capital Expenditure & Pearson Correlation & 1 & .338 \\
& Sig. (2-tailed) & & .170 \\
& $\mathrm{~N}$ & 18 & 18 \\
\hline Real Fishing & Pearson Correlation & .338 & 1 \\
& Sig. (2-tailed) & .170 & \\
& $\mathrm{~N}$ & 18 & 18 \\
\hline
\end{tabular}

Table 10: Correlation 4.2

Correlation tests conducted separately federal capital expenditure and fishing $(\mathrm{p}=.314, \mathrm{r}=.204)$ and real fishing $(\mathrm{p}=.338, \mathrm{r}=.170)$ found weak insignificant positive relationships in both cases.

Based on this, there is insufficient evidence to reject $\mathrm{H}_{0}$.

Testing Hypothesis 5

$\mathrm{H}_{0}$ There is no significant relationship between federal capital expenditure and Agriculture.

$\mathrm{H}_{1}$ There is a significant relationship between federal capital expenditure and Agriculture.

\section{Correlations}

\begin{tabular}{|ll|l|l|}
\hline & & Federal Capital Expenditure & Agriculture \\
\hline Federal Capital Expenditure & Pearson Correlation & 1 & 403 \\
& Sig. (2-tailed) & & .097 \\
& $\mathrm{~N}$ & 18 & 18 \\
\hline Agriculture & Pearson Correlation & .403 & 1 \\
& Sig. (2-tailed) & .097 & \\
& $\mathrm{~N}$ & 18 & 18 \\
\hline
\end{tabular}

Table 11: Correlation 5.1 


\section{Correlations}

\begin{tabular}{|ll|l|l|}
\hline & & Federal Capital Expenditure & Real Agriculture \\
\hline Federal Capital Expenditure & Pearson Correlation & 1 & .440 \\
& Sig. (2-tailed) & & .068 \\
& $\mathrm{~N}$ & 18 & 18 \\
\hline Real Agriculture & Pearson Correlation & .440 & 1 \\
& Sig. (2-tailed) & .068 & \\
$\mathrm{~N}$ & 18 & 18 \\
\hline
\end{tabular}

Table 12: Correlation 5.2

Federal capital expenditure is found to have a moderate insignificant relationship with overall agricultural activity in nominal $(\mathrm{p}=.403, \mathrm{r}=.097)$ and real terms $(\mathrm{p}=.440, \mathrm{r}=.068)$.

Based on this, there is insufficient evidence to reject $\mathrm{H}_{0}$.

5.3 Summary of results

\begin{tabular}{|l|l|l|l|l|l|}
\hline Hypothesis & Independent Variable & Dependent Variable & Relationship & Significance & Null Hypothesis \\
\hline 1 & FCE & Crops & Positive & Not significant & Accept \\
\hline 2 & FCE & Livestock & Positive & Not significant & Accept \\
\hline 3 & FCE & Forestry & Positive & Not significant & Accept \\
\hline 4 & FCE & Fishing & Positive & Not significant & Accept \\
\hline 5 & FCE & Agriculture & Positive & Not significant & Accept \\
\hline
\end{tabular}

Table 13: Summary

\section{Conclusions and Recommendations}

Test findings show a relationship similar to the pattern of our theories in that government expenditure had a positive relationship with subsectors of agriculture and overall agricultural activity. But this relationship was ultimately found to be insignificant and thus could not confirm that an increase in government spending resulted in an increase in government spending.

However, though it is evident that the governments reliance on spending to solely stimulate the sector is not sustainable, one cannot simply rule out government spending as an important tool to improve agricultural activity but must instead be used in sync with other policies that favor the industry. Furthermore, because corruption may negate the effects of spending and distort reports of findings there is also the need for more transparent and accountable spending in the sector.

\section{List of References}

Ademola, I.S., Ajayi, EO \& Femi, E 2013. Government Expenditure on Agricultural Sector and Economic Growth in Nigeria 1981-2010. ISOR Journal of Humanities and Social Science, vol. 8, no. 4, pp 62-67.

Adofu, I, Abula, M \& Agama, JE, 2012, "The effects of government budgetary allocation to agricultural output in Nigeria" Sky Journal of Agricultural Research, vol. 1, no. 1, pp.1-5.

Apata, T.G., Sanusi, R.A., Obaisi, A. and Ajani, O., 2016, September. Exploration of public spending and agricultural growth. Comparative analysis of Nigerian and Malaysian agricultural growth (1970-2010). In 2016 AAAE Fifth International Conference, September 23-26, 2016, Addis Ababa, Ethiopia (No. 246922). African Association of Agricultural Economists (AAAE).

Budget Office of the Federation, "Budget Documents", available at: http://www.budgetoffice.gov.ng/index.php/resources/internal-resources/budget-documents

Central Bank of Nigeria, 2017, "Monetary Policy, Decisions". Available at: http://www.cbn.gov.ng/monetaryPolicy/decisions.asp

Chandio, A.A., Jiang, Y., Rehman, A. and Jingdong, L., 2016. Impact of Government Expenditure on Agricultural Sector and Economic Growth in Pakistan. International Journal of Advanced Biotechnology and Research, 7(3), pp.1046-1053

Ebere, C. and Osundina, K.C., 2014. Government expenditure on agriculture and economic growth in Nigeria. Int Journal of Science and Research, 9(3), pp.188-194.

Iganiga, B.O. and Unemhilin, D.O., 2011. The impact of federal government agricultural expenditure on agricultural output in Nigeria. Journal of Economics, 2(2), pp.81-88.

Jambo, N., 2017. The impact of government spending on agricultural growth: a case of Zambia, Malawi, South Africa and Tanzania (Doctoral dissertation, Stellenbosch: Stellenbosch University).

Jaroensathapornkul, J. and Tongpan, S., 2007. Impacts of Government Spending on Thailand's Agricultural Sector (Doctoral dissertation, Kasetsart University). 
Keynes, J.M., 1937. The general theory of employment. The quarterly journal of economics.

Lawal WA 2011, "An Analysis of Government Spending on Agricultural Sector And Its Contribution To GDP In Nigeria”, International Journal of Business and Social Sciences, vol. 2 no. 20.

Olomola, A.S., Mogues, T., Olofinbiyi, T., Nwoko, C., Udoh, E., Alabi, R.A., Onu, J. and Woldeyohannes, S., 2014. Analysis of agricultural public expenditures in Nigeria: Examination at the federal, state, and local government levels, International Food Policy Research Institute.

Selvaraj, K.N., 1993. Impact of government expenditure on agriculture and performance of agricultural sector in India. Bangladesh Journal of Agricultural Economics, 16(2).

Shevchuk, Victor. and Kopych, Roman., 2017. Modelling of fiscal policy effects on agriculture and industry in Ukraine. Information Systems in Management, 6.

Shuaib, I.M., Igbinosun, F.E. and Ahmed, A.E., 2015. Impact of Government agricultural expenditure on the growth of the Nigerian economy. Asian Journal of Agricultural Extension, Economics and Sociology, 6(1), pp.23-33.

Wagle, T.P.S., 2016. Government Expenditure in Agriculture Sector of Nepal: An Empirical Analysis. Global Journal of Agricultural Research, 4(3), pp.1-12. 